\title{
Epizootic papillomas in brown bullheads Ictalurus nebulosus from Silver Stream reservoir, New York
}

\author{
Paul R. Bowser ${ }^{1, *}$, Marilyn J. Wolfe $e^{1 * *}, J_{u l i e}$ Reimer $^{2, * * *}$, Barbara S. Shane $^{3}$ \\ ${ }^{1}$ Department of Avian and Aquatic Animal Medicine, College of Veterinary Medicine, Cornell University, Ithaca, \\ New York 14853, USA \\ ${ }^{2}$ Department of Agronomy; ${ }^{3}$ Institute ior Environmental Studies, Louisiana State University, Baton Rouge, Louisiana 70803 , \\ USA
}

\begin{abstract}
Fish from Silver Stream reservoir in Newburgh, New York (USA) were examined in 1985 and 1986 following reports by fishermen who had found a high prevalence of skin lesions in brown bullheads Ictalurus nebulosus caught in the reservoir Oral and skin papillomas were found in $43.2 \%$ and $60.0 \%$ of the brown bullheads from these respective samplings, whereas no papillomas were found in yellow bultheads I. natalis. No viral particles could be identified by electron microscopy in the lesions nor were cytopathic effects observed in primary cell cultures of tumor cells or from cocultivation of these cells with an established brown bullhead cell line. Extracts of the sediment from the reservoir contained known promutagens but the concentrations of these compounds were low and similar to those found at reference sites considered to be non-contaminated. Nevertheless a positive response in the Ames assay of the extracts of the sediment was recorded. Elevated levels of chromium, copper, manganese, lead and vanadium were found in the sediments and copper, manganese, nickel, strontium and lead were elevated in the water. The $\mathrm{pH}$ of the interstitial water was 4.5. It is unlikely that any of these parameters was the sole causative factor in the etiology of the papillomas.
\end{abstract}

\section{INTRODUCTION}

The etiology of neoplasia in animals including fish is thought to be multifaceted - with pollutants, viruses, diet, animal age and physical environmental conditions contributing to the development of this disease. The first report suggesting that neoplasms in fish might be correlated with environmental contaminants was published by Russel \& Kotin (1957). They described papillomas in white croaker Genyonemus lineatus collected from Los Angeles Harbor (USA) and ascribed the lesions to exposure to a sewage outfall. Young (1964) reported a similar condition in Dover sole Microstomus pacificus and suggested that pollutants from sewage outfalls were the likely cause.

Neoplasms in fish are assumed to be more common in bottom-dwelling and bottom-feeding species inhabiting waters heavily polluted with industrial and

\footnotetext{
- Addressee for correspondence

Present addresses:

- Experimental Pathology Laboratories, Inc., PO Box 474. Herndon, Virginia 22070, USA.

.. Columbia Analytical Services, 1317 South 13th Street, Kelso, Washington 98626, USA
}

agricultural wastes than in animals living in the epilimnion or metalimnion (Mix 1986). This hypothesis has been proposed because many carcinogenic and mutagenic hydrophobic pollutants, such as highmolecular-weight polycyclic aromatic hydrocarbons (PAH), are adsorbed to bottom sediments. As these compounds are highly lipophilic they can be readily absorbed from water, sediments and food by exposed fish (Neff et al. 1976, Malins \& Hodgins 1981). Fish hepatic enzymes metabolize many PAH to intermediates that bind with DNA, a process that may lead to the initiation of tumors (Malins \& Hodgins 1981). PAH have been implicated in the etiology of papillomas and epidermal carcinomas in bottom-dwelling freshwater brown bullheads Ictalurus nebulosus (Harshbarger 1981, Baumann et al. 1982, Black 1983b, Baumann \& Harshbarger 1985) and white suckers Catostomus commersoni (Sonstegard 1977). PAH have also been implicated as the etiological agent of hepatic neoplasia in fish from highly polluted sites (Smith et al. 1979, Malins et al. 1987). Although these particular studies have implicated pollutants as the etiological agents of neoplasia in fish, other workers have refuted this association (Hard et al. 1979, Kurelec et al. 1981). 
A viral etiology had been proposed for papillomas in eels Anquilla anquilla from the Elbe river, Germany (Möller 1984). The highest prevalence of papillomas was found in eels from regions of the river with a relatively low level of pollution, and it was postulated that the papilloma virus was activated via salinity stress. This study also suggested that polluted sediments were not associated with skin neoplasia in bottom-dwelling fish, since other tumors were found only in smelt, a midwater inhabitant. A viral etiology has also been proposed for lymphosarcoma in 2 members of the pike family Esocidae (Mulcahy \& O'Leary 1970 , Sonstegard 1976), and a retrovirus has been proven for dermal sarcoma in walleye Stizostedion vitreum (Martineau et al. 1990).

During Summer 1985, fishermen at Silver Stream Reservoir, New York (USA) found in their catch a number of brown bullheads with proliferative lesions in the oral cavity and on the skin. Although both brown and yellow bullheads inhabited the reservoir, there were no reports of yellow bullheads with the lesions. In October 1985, a site collection was conducted. The prevalence of skin lesions in brown and yellow bullheads was $43.4 \%(49 / 113)$ and $3.4 \%(3 / 87)$, respectively. Histological evaluation of tissues from 27 brown bullheads and 1 yellow bullhead revealed the lesions to be papillomas and a hemangioma, respectively. This 1985 finding of a high prevalence of papillomas in brown bullheads led us to conduct a second collection in October 1986 with a more detailed processing of fish and collection of water and sediment samples from the reservoir. In this study the sediment was separated into 4 fractions, characterized chemically by gas chromatography $(\mathrm{GC})$ and evaluated for mutagenic activity using Ames assay. Sediments were also analyzed for metals by inductively coupled argon plasma spectrometry (ICAP) and water quality parameters were determined.

\section{MATERIALS AND METHODS}

Collection of fish. Fish were collected from Silver Stream Reservoir, a shallow water body 475 ha in area with a maximum depth of $5 \mathrm{~m}$, owned by the City of Newburgh in Orange County, New York (USA). Four trap nets were set in 1.2 to $2.2 \mathrm{~m}$ water depth for ca $25 \mathrm{~h}$ at different sites in the reservoir (Fig. 1). An inventory of all fish captured in the net was taken. The number of brown and yellow bullheads with and without oral and skin lesions was recorded. Twelve brown bullheads with gross proliferative skin lesions and 13 yellow bullheads without grossly visible lesions were transported alive to the College of Veterinary Medicine (CVM), Cornell University, Ithaca, New York, for histological

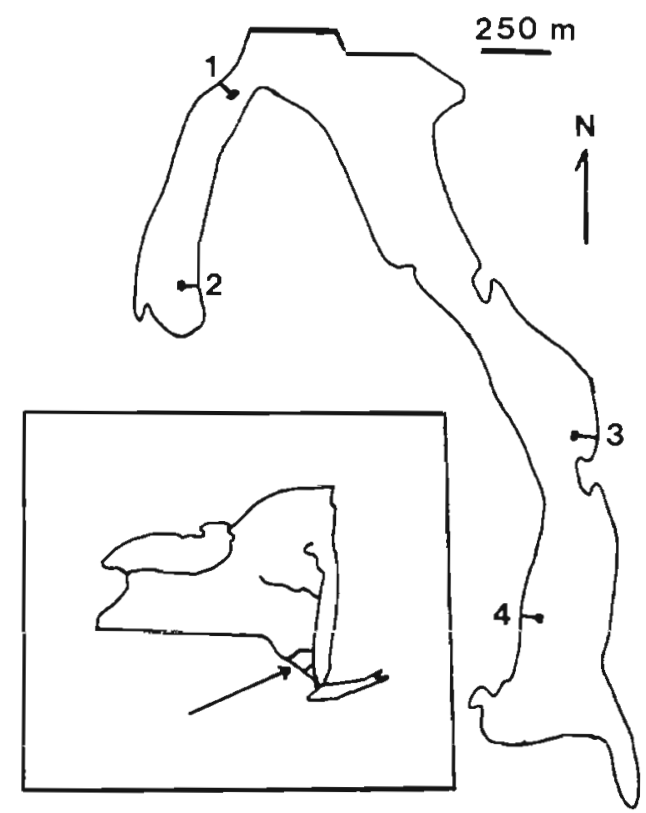

Fig. 1. Silver Stream Reservoir, Orange County, New York (USA), with locations of 4 trapnets used to collect fish in October 1986. Inset: location of Orange County, New York State, USA

processing and isolation of enzyme fractions. All remaining fish were returned alive to the reservoir. Sediment samples from the reservoir were collected at the locations of the trap nets for chemical analysis.

Control brown bullheads were obtained from a hatchery in New York State and shipped alive to Louisiana State University. Concomitantly, sediment from the hatchery pond was shipped with the fish for analysis.

Necropsy procedure. For each fish this procedure consisted of: (a) recording of length, weight, sex and documentation of any grossly visible lesions; (b) collection of liver, anterior and posterior kidney, spleen, heart, stomach, proximal and distal intestine, gonad, lateral line, skeletal muscle, skin and representative gross lesions for histopathology; (c) removal of remaining proliferative lesions from each of 11 fish with papillomas for virus isolation attempts. In addition, papilloma tissue was fixed in $3 \%$ glutaraldehyde and processed for examination (Weakley 1972) with a Philips 301 transmission electron microscope.

Virus isolation attempts. A portion of the tissue with lesions was digested in $0.25 \%$ trypsin- $-0.02 \%$ EDTA at $5^{\circ} \mathrm{C}$ for ca $18 \mathrm{~h}$. The digest was then passed through sterile gauze to remove large undigested tissue fragments. The filtrate, containing primarily single cells, was washed twice with sterile phosphate buffered saline (PBS) and the cells were used to initiate both primary cell cultures and co-cultivated with an established brown bullhead cell line (ATCC CCL \#59). Cell 
culture medium in all cases was Eagle's Minimal Essential Medium with Hank's salts, supplemented with 10\% fetal bovine serum, 1\% L-glutamine and antibiotics $\left(100 \mathrm{IU} \mathrm{ml}^{-1}\right.$ penicillin, $100 \mu \mathrm{g} \mathrm{ml}^{-1}$ streptomycin, $2.5 \mu \mathrm{g} \mathrm{ml}^{-1}$ amphotericin B). All cultures were incubated at $25^{\circ} \mathrm{C}$ for $6 \mathrm{wk}$, and observed throughout for cytopathic effects. They were then subcultured once after $4 \mathrm{wk}$ and observed for an additional $2 \mathrm{wk}$.

A commercially available diagnostic kit for bovine papilloma virus (Dakos, Carpinterria, CA) was applied to preparations from the proliferative lesions in an effort to detect papilloma virus antigen. The kit was used according to manufacturer's instructions against paraffin sections of different representative proliferative lesions from each of the 11 brown bullheads. A canine papilloma biopsy served as a positive control.

Extraction of sediments. Grab samples of sediment collected in October 1986 from Silver Stream Reservoir were placed in glass, acid-washed jars and covered with foil to protect the contents. Fish hatchery pond sediment samples were shipped with the control fish in May 1988. Sediments were kept at $-20^{\circ} \mathrm{C}$ until analyzed. Each sediment was air-dried and stored in glass jars with teflon-lined lids. The moisture content of the sediments was determined by the method of Gardner (1965).

The air-dried sediments were extracted and fractionated according to the method of Pesch et al. (1987). Approximately 40 to $60 \mathrm{~g}$ of sediment were sonicated with acetonitrile then back-extracted into pentane, and reduced in volume using a vacuum rotary evaporator. The extract was applied to a column containing 100 to 200 mesh silica gel and fractionated by elution with $100 \%$ pentane (Fraction 1), $85 \%$ pentane : $15 \%$ dicholoromethane (DCM) (Fraction 2), 100\% DCM (Fraction 3), and $100 \%$ methanol (Fraction 4). Each fraction was reduced in volume, then divided into 2 aliquots and stored in separate vials. The contents of one vial was analyzed for its chemical constituents and the second for its mutagenic activity using the Ames assay. Extracts for testing in the Ames assay were taken to dryness and resuspended in dimethyl sulfoxide (DMSO). Hexamethylbenzene was added as an internal standard to the extracts before chemical analysis. For samples analyzed by gas chromatography/mass spectrometry (GC/MS), $1.6 \mathrm{ng} \mathrm{g}^{-1} \mathrm{~d}-10$ acenaphthene $\mathrm{d}-10$ phenanthrene and $\mathrm{d}-12$ chrysene and $3.3 \mathrm{ng} \mathrm{g}^{-1}$ d-12 perylene were added before extraction.

Chemical analysis of sediments. Organic components: Fractions ( $1 \mu \mathrm{l}$ aliquots) were analyzed using a Model HP 5890A gas chromatograph (GC) with a flame ionization detector (FID). A fused $30 \mathrm{M}$ silica capillary column, $0.25 \mathrm{~mm}$ I.D., with a $0.25 \mu \mathrm{m}$ film of DB-5 (J and W. Scientific, Inc., Folsom, CA) was used. The

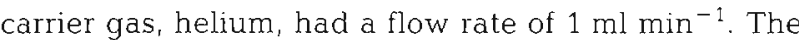
detector temperature was $300^{\circ} \mathrm{C}$, that of the injection port, $235^{\circ} \mathrm{C}$. For analysis the initial temperature of the column of $50^{\circ} \mathrm{C}$ was held for 3 min, then ramped at $8^{\circ} \mathrm{C}$ $\mathrm{min}^{-1}$ to $280^{\circ} \mathrm{C}$ and held for $18 \mathrm{~min}$. The identity of each PAH from Silver Stream and control site sediment samples was determined by comparison with the relative retention times (RRT) of each peak from a 16 component PAH standard mixture. The RRT for each peak was calculated by dividing the retention time (RT) of a sample by the RT of the surrogate standard, hexamethylbenzene (HMB). Therefore, by definition, the RRT of HMB is equal to 1.0. The concentration of each compound (ng PAH on column) was calculated by multiplying the area by the response factor for each component. The PAH concentration in the sediment (ng $\mathrm{g}^{-1}$ ) was then calculated by taking into account the dry weight of the sediment and the dilution factor. Fraction 2 was also analyzed by GC/MS using the same analytical parameters used for GC. A Hewlett Packard HP 5970 mass spectrometer was interfaced with the HP $\mathrm{GC}$. The mass range of 45 to 450 amu was scanned.

Inorganic components: Sediments were extracted using 3 different methods, each of which gave optimal recoveries with specific metals. Titanium, vanadium, sulfur, silicon and sodium were extracted according to the method of Bernas (1968). Copper, nickel, iron, zinc, manganese, calcium, chromium, lead, magnesium, arsenic and cadmium were extracted using a modified Environmental Protection Agency (1981) method. Mercury was determined by the method of Hatch \& Ott (1968). As cadmium and arsenic concentrations were low, they were measured by the method of standard addition.

Extracts were analyzed by Inductively Coupled Argon Plasma-Atomic Emission Spectrometer Model ARL 34000 (ICAP) equipped with a Gilson Autosampler and quantified using a standard calibration curve. The R.F. generator was operated at $1200 \mathrm{~W}$ forward power. The solution aspiration rate was $2.5 \mathrm{ml} \mathrm{min}^{-1}$ and each sample was pre-flushed for $30 \mathrm{~s}$, followed by three $10 \mathrm{~s}$ integrations. The concentration of each sample, which was reported as total $\mu \mathrm{g}$ element $\mathrm{g}^{-1}$ sediment, was the average of 3 integrations corrected for the dilution and reagent blank.

Chemical analysis of interstitial water. A frozen sediment sample from Silver Stream Reservoir was thawed and the water was separated from the sediment by vacuum filtration through Whatman No. 42 filter paper. The $\mathrm{pH}$ of the water was measured by standard methods (EPA 1983). The remaining solution was passed through a $0.45 \mu \mathrm{m}$ porosity membrane filter and acidified to $\mathrm{pH} 2$ with nitric acid. Duplicate samples were then analyzed in duplicate for copper, nickel, zinc, chromium, vanadium, lead, cadmium, cobalt, arsenic, manganese, iron, silicon, sulfur, magnesium, aluminium, calcium, phosphorus, sodium, potassium, 
beryllium and strontium by ICAP Instrument parameters were the same as described above.

Preparation of hepatic S9 and microsomes. Liver S9 was prepared according to standard techniques (Guengerich 1977, Lake 1987). Fish were killed by decapitation and livers excised, weighed and homogenized in ice cold, sterile buffer containing $0.25 \mathrm{M}$ sucrose, $10 \mathrm{mM}$ Tris, $\mathrm{pH} 7.4$ and $1.0 \mathrm{mN}$ EDTA. The resulting homogenate was fractionated by sequential centrifugation at 2000 and $9000 \times g$. The supernatant fluid from the second centrifugation $(9000 \times \mathrm{g})$, known as $\mathrm{S} 9$, was stored in sterile $1 \mathrm{ml}$ vials at $-80^{\circ} \mathrm{C}$ until use.

The S9 fractions prepared at Cornell University were shipped frozen under dry ice to Louisiana State University for further studies. Twelve S9 fractions were prepared from both brown (10 male and 2 female) and yellow ( 8 male and 4 female) bullheads from the second sampling date (Oct 1986) and from brown bullheads ( 7 male and 7 female) obtained from a third sampling (Jul 1987). The livers from the 40 control immature brown bullheads were pooled without consideration of sex before isolation of $\mathrm{S} 9$.

Rat S9 was prepared from male Sprague-Dawley rats which were induced by the administration of Aroclor $1254\left(500 \mathrm{mg} \mathrm{kg}^{-1}\right)$ as a single intraperitoneal injection 5 d before sacrifice. Rodent hepatic S9 was isolated by the same method as described above for fish preparations.

The protein concentration of the S9 preparations was determined by the method of Lowry et al. (1951), using bovine serum albumin as the reference standard.

Ames mutagenicity assay. Salmonella typhimurium TA98 and TA100 were kindly donated by Dr Bruce Ames, University of California, Berkeley, CA (USA). Overnight cultures for experiments were prepared by adding $0.1 \mathrm{ml}$ of the tester strain to $25 \mathrm{ml}$ of Oxoid nutrient broth No. 2 ( $\mathrm{KC}$ Biologicals, Lexena, KS) and incubating for $14 \mathrm{~h}$ at $37^{\circ} \mathrm{C}\left(1\right.$ to $\left.2 \times 10^{9} \mathrm{cells} \mathrm{ml}{ }^{-1}\right)$.

To assess the activation potential of enzymes from exposed and control fish and rats, S9 from these 3 sources were used in assaying for the presence of mutagens in the sediments. The S9 was fortified with $5 \mathrm{mM}$ glucose-6-phosphate, $4 \mathrm{mM}$ NADP, $100 \mathrm{mM}$ sodium phosphate buffer ( $\mathrm{pH} 7.4$ ) $8 \mathrm{mM} \mathrm{MgCl}_{2}$ and $33 \mathrm{mM} \mathrm{KCl}$ (Maron \& Ames 1983). For all studies, $1.0 \mathrm{mg}$ of $\mathrm{S} 9$ protein per plate was used. The S 9 mixture was sterilized by sequential filtration through $0.45 \mu \mathrm{m}$ and a $0.2 \mathrm{um}$ porosity membrane filters. Positive and negative controls were used in each experiment. For Salmonella typhimurium TA100 and TA98, the direct acting mutagens sodium azide (20 $\mu \mathrm{g}$ plate) and 2nitrofluorene $(5.0 \mathrm{\mu g}$ plate) were used, respectively The negative control contained DMSO.

The preincubation protocol described by Maron \&
Ames (1983) was used. In this procedure a $0.1 \mathrm{ml}$ aliquot of an overnight culture of bacteria was placed in a sterile test tube followed by varying volumes of sediment extract and DMSO to $100 \mu \mathrm{l}$ and either $0.5 \mathrm{ml}$ of $0.1 \mathrm{M}$ phosphate buffer or $0.5 \mathrm{ml}$ of the fish or rat $\mathrm{S} 9$ mix in a total volume of $0.7 \mathrm{ml}$. Tubes were incubated for $20 \mathrm{~min}$ at $28^{\circ} \mathrm{C}$ with fish $\mathrm{S} 9$ then $2 \mathrm{ml}$ top agar containing a $0.5 \mathrm{mM}$ histidine/biotin solution was added. The contents of each tube were mixed and poured onto Petri dishes containing bottom agar fortified with $2 \%$ glucose and Vogel Bonner salts. When S9 from rats replaced fish S9, preincubation was at $37^{\circ} \mathrm{C}$ for $20 \mathrm{~min}$.

After incubation of the plates at $37^{\circ} \mathrm{C}$ for $48 \mathrm{~h}$, the revertant colonies were scored using a Biotran Il Colony Counter (New Brunswick Scientific, Eäison, iNJj. The criterion of mutagenicity was either a doubling of the background reversion rate or a dose-dependent increase in the number of revertants with increasing volumes of sediment extracts.

Statistical treatment of data. Statistical differences between the means of 2 measured values were calculated by first determining the pooled standard deviation $\left(s_{p}\right)$ from the 2 estimated standard deviations $\left(s_{a}\right.$ and $s_{b}$ ) of the 2 measured values $\left(x_{a}\right.$ and $\left.x_{b}\right)$. The statistical uncertainty (U) of the difference between the means of the 2 measured values $\left(x_{a}\right.$ and $x_{b}$ ) was then calculated. The difference between the 2 means $(\Delta=$ $\mathrm{x}_{\mathrm{a}}-\mathrm{x}_{\mathrm{b}}$ ) was then compared to the statistical uncertainty (U). If $\Delta \leq U$ then the 2 means are not statistically different from one another at the confidence level examined.

Statistical analysis of the data was performed to determine whether significant differences existed between individual fish within a species or between sampling years (1986 and 1987).

\section{RESULTS}

\section{Necropsy results}

During the 1986 collection, a total of 95 brown bullheads Ictalurus nebulosus and 96 yellow bullheads $I$. natalis from Silver Stream Reservoir were examined on site. The prevalences of proliferative oral and skin lesions on fish from the 4 collection sites are summarized in Table 1 . The overall prevalence of these lesions for brown and yellow bullheads was 60 and $0 \%$, respectively. The external lesions in the 12 brown bullheads brought back to CVM were diagnosed histologically as papillomas. All 12 fish had oral papillomas and 8 had papillomas of the skin. Other less prevalent lesions observed during necropsy included: hepatocellular carcinoma with metastases to spleen and kidney 
Table 1 Ictalurus nebulosus and $l$. natalis. Prevalence of oral and skin papillomas in fish collected from Silver Stream Reservoir, New York in October 1986

\begin{tabular}{|ccc|}
\hline Site & $\begin{array}{c}\text { Ictalurus nebulosus } \\
\text { Fraction w/lesions }(\%)\end{array}$ & $\begin{array}{c}\text { Ictalurus natalis } \\
\text { Fraction w/lesions }(\%)\end{array}$ \\
\hline 1 & $21 / 36(58.3 \%)$ & $0 / 7(0 \%)$ \\
2 & $18 / 23(78.3 \%)$ & $0 / 0(0 \%)$ \\
3 & $11 / 26(42.3 \%)$ & $0 / 75(0 \%)$ \\
4 & $7 / 10(70.0 \%)$ & $0 / 4(0 \%)$ \\
Total & $57 / 95(60.0 \%)$ & $0 / 86(0 \%)$ \\
\hline
\end{tabular}

(1 fish, Registry of Tumors in Lower Animals, Smithsonian Institution, Washington, D.C., RTLA No. 3785), bile duct adenoma and hepatocellular adenoma (1 fish), hepatocellular adenoma (1 fish) and neurofibroma (1 fish, RTLA No. 3784 and 3787). No neoplasms were identified in the 13 yellow bullheads brought to CVM in 1986 for detailed necropsy and histopathological examination.

Papillomas of the epithelium were usually distributed in both dorsal and ventral aspects of the oral cavity. They often protruded from the mouth and involved adjacent skin of the upper and lower jaws (Fig 2). Papillomas of the skin occurred in other locations, particularly on the ventral surface of the head, barbels and operculum, and to a lesser degree on the lateral and ventral aspects of the trunk. Histologically. the papillomas had a typical cauliflower appearance. The proliferating surface epithelium was thickened and thrown up into folds. Thin strands of connective tissue with vasculature from the oral submucosa (oral papillomas) or dermis (skin papillomas) extended into the epithelial folds. The integrity of the epithelial basement membrane remained intact (Fig. 3).

Fig. 2. Ictalurus nebulosus. Multiple oral papillomas on an individual from Silver Stream Reservoir, Orange County, New York. Bar $=$ $1 \mathrm{~cm}$

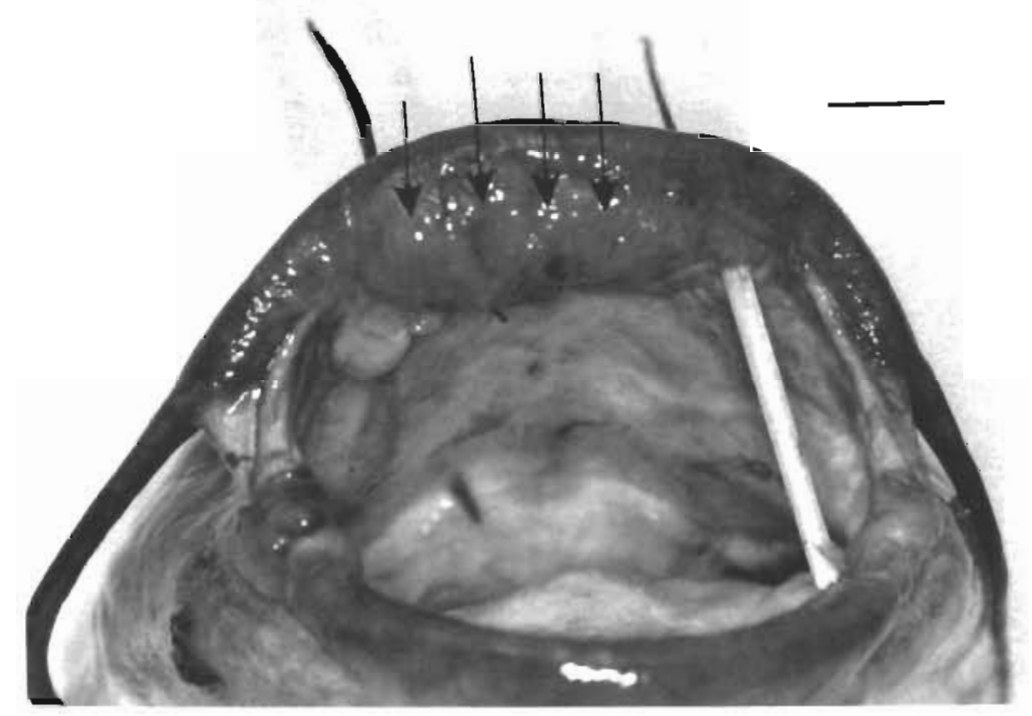

Fig. 3. Ictalurus nebulosus. Low-power photomicrograph of an oral papilloma from an individual collected from Silver Stream Reservoir, Orange County, New York. Note typical cauliflower appearance of the papilloma. Bar $=100 u \mathrm{~m}$

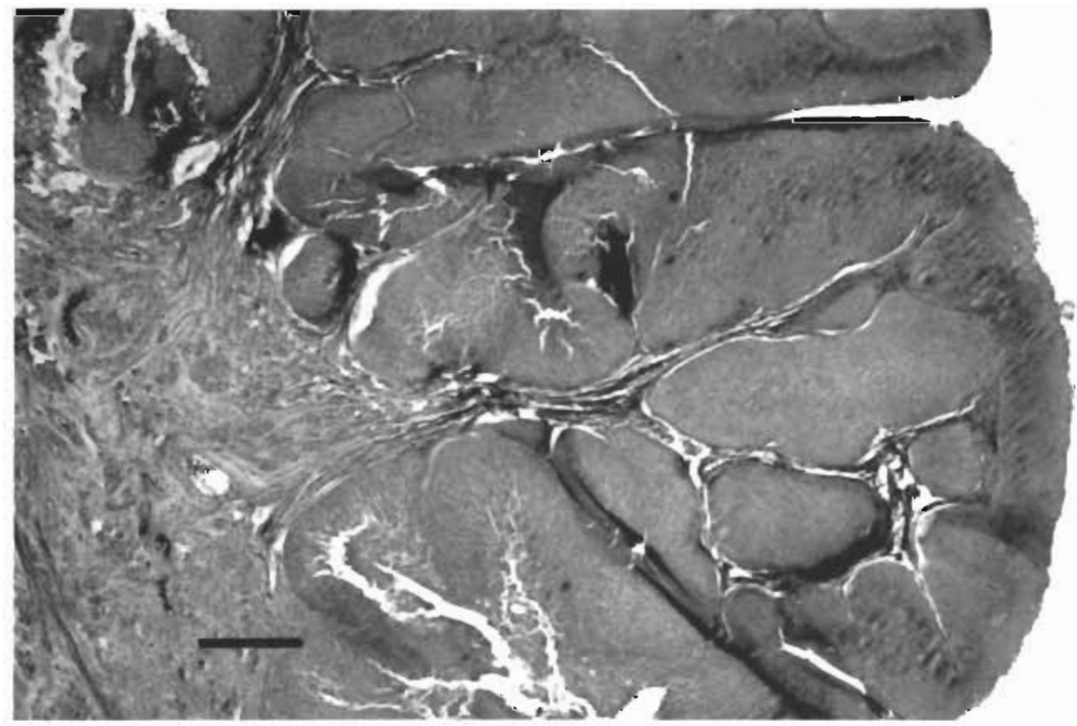


Table 3. Evaluation of the mutagenicity of 4 fractions of the extract of sediment collected from Station 1 from Silver Stream Reservoir in the Ames assay using Salmonella typhimurium TA100 ${ }^{\mathrm{a}}$

\begin{tabular}{|c|c|c|c|c|c|}
\hline \multirow{2}{*}{$\begin{array}{l}\text { Fraction and } \\
\text { S9 sources }\end{array}$} & \multicolumn{5}{|c|}{$\mu$ of fraction plate ${ }^{-1}$} \\
\hline & $0^{c}$ & 10 & 30 & 50 & 100 \\
\hline \multicolumn{6}{|l|}{ Fraction 1} \\
\hline No 59 & $66 \pm 2^{d}$ & $64 \pm 19$ & $64 \pm 7$ & $66 \pm 7$ & $46 \pm 4$ \\
\hline YBH & $66 \pm 11$ & $74 \pm 1$ & $75 \div 10$ & $60 \pm 4$ & $40 \pm 15^{+}$ \\
\hline $\mathrm{BBH}$ & 61 & $79 \pm 4$ & $83 \div 3$ & $87 \pm 5$ & $45 \pm 2^{+}$ \\
\hline Rat & $78 \pm 8$ & $87 \pm 11$ & $79 \pm 1$ & $96 \pm 13$ & $50 \pm 10^{+}$ \\
\hline \multicolumn{6}{|l|}{ Fraction 2} \\
\hline No S9 & $66 \pm 2$ & $67 \pm 10$ & $61 \pm 2$ & $58 \pm 16$ & $57 \pm 1$ \\
\hline $\mathrm{YBH}$ & $66 \pm 11$ & $80 \pm 1$ & $81 \pm 7$ & $70 \pm 4$ & $51 \pm 8$ \\
\hline $\mathrm{BBH}$ & 61 & $74 \pm 2$ & 74 & $78 \pm 8$ & $59 \pm 1$ \\
\hline Rat & $78 \pm 8$ & $100 \pm 13$ & $98 \pm 18$ & $119 \pm 21^{\circ}$ & $126 \pm 6^{\circ}$ \\
\hline \multicolumn{6}{|l|}{ Fraction 3} \\
\hline No S9 & $66 \pm 2$ & $70 \pm 12$ & $69 \pm 1$ & $73 \pm 30$ & $61 \pm 15$ \\
\hline YBH & $66 \pm 11$ & $68 \pm 1$ & $69 \pm 2$ & $66 \pm 4$ & $59 \pm 2$ \\
\hline $\mathrm{BBH}$ & 61 & $66 \pm 7$ & $79 \pm 3$ & $63 \pm 1$ & $53 \pm 8$ \\
\hline Rat & $78 \pm 8$ & $84 \pm 5$ & $104 \pm 1^{\circ}$ & $82 \pm 15$ & $73 \pm 8$ \\
\hline \multicolumn{6}{|l|}{ Fraction 4} \\
\hline No S9 & $66 \pm 2$ & $75 \pm 13$ & $68 \pm 5$ & $68 \pm 1$ & $60 \pm 19$ \\
\hline YBH & $66 \pm 11$ & $62 \pm 11$ & $64 \pm 6$ & $74 \pm 7$ & $58 \pm 1$ \\
\hline $\mathrm{BBH}$ & 61 & $72 \pm 6$ & $80 \pm 3$ & $71 \pm 3$ & $60 \pm 19$ \\
\hline Rat & $78 \pm 8$ & $86 \pm 6$ & $94 \pm 13$ & $81 \pm 9$ & $91 \pm 1$ \\
\hline \multicolumn{6}{|c|}{ Sediment obtained from Station 1, Sample A (Table 3, Column 1) } \\
\hline \multicolumn{6}{|c|}{ b $\mathrm{S} 9$ included at $1.0 \mathrm{mg}$ protein plate ${ }^{-1}$} \\
\hline \multicolumn{6}{|c|}{ Background reversion rate } \\
\hline \multicolumn{6}{|c|}{ d Mean \pm SD of 2 plates; background reversion rate not subtracted } \\
\hline \multicolumn{6}{|c|}{ + Toxicity observed on plate } \\
\hline Significantly & $=0.05)$ fron & nd reversi & & & \\
\hline
\end{tabular}

Table 4. Concentration of PAH (ng $\mathrm{g}^{-1}$ ) in Fraction 2 of sediment samples from 2 stations (1 and 3) from Silver Stream Reservoir and the control site as determined by GC-FID analysis ${ }^{a}$

\begin{tabular}{|c|c|c|c|c|c|c|}
\hline \multirow{2}{*}{ Compound } & \multicolumn{4}{|c|}{ Silver Stream station ${ }^{b}$} & \multicolumn{2}{|c|}{ Hatchery control site ${ }^{c}$} \\
\hline & $1-\mathrm{A}$ & $1-\mathrm{B}$ & $3-\mathrm{A}$ & $3-B$ & $1-\mathrm{A}$ & $1-\mathrm{B}$ \\
\hline Fluorene & $<\mathrm{DL}^{\mathrm{d}}$ & 4 & 28 & $<\mathrm{DL}$ & 52 & ND \\
\hline Phenanthrene & 10 & 330 & $N D^{e}$ & 73 & $<\mathrm{DI}$ & $<\mathrm{DL}$ \\
\hline Fluoranthene & 87 & 200 & 360 & 250 & ND & ND \\
\hline Pyrene & 31 & 110 & 120 & 190 & 4 & 5 \\
\hline Benz(a)anthracene & 31 & 70 & 140 & 74 & $<\mathrm{DI}$ & 4 \\
\hline Chrysene & 44 & 100 & 180 & 110 & 4 & 6 \\
\hline Benzo(b)fluoranthene ${ }^{*}$ & 32 & 30 & 31 & ND & 4 & 4 \\
\hline Benzo(k)fluoranthene ${ }^{* *}$ & 10 & 230 & 96 & 250 & ND & 4 \\
\hline Benzo(a)pyrene & 31 & 70 & 120 & 75 & 6 & 4 \\
\hline Indeno $(1,2,3$-cd)pyrene & 17 & 43 & ND & 47 & ND & ND \\
\hline Dibenz(ah)anthracene & ND & 16 & ND & ND & ND & ND \\
\hline Benzo(ghi)perylene & 32 & 39 & ND & 59 & 9 & 14 \\
\hline Total PAH & 325 & 1238 & 1047 & 1128 & 79 & 41 \\
\hline \multicolumn{7}{|c|}{$\begin{array}{l}\text { Neither acenaphthene nor anthracene was detected in either sediment } \\
\text { b Four extractions were undertaken on Silver Stream sediment, the first } 2 \text { samples were extracted from Station } 1 \text { (A and B), the } \\
\text { second } 2 \text { from Station } 3 \text { (A and B) } \\
\text { c Two extractions (A and B) were undertaken on the single Control Site sediment sample obtained } \\
\text { d }<\text { DL detection limit was } 2 \text { ng on column; compound was present but not quantifiable } \\
\text { e ND no peak obtained } \\
{ }^{*} \text { Carcinogenic PAH }\end{array}$} \\
\hline
\end{tabular}




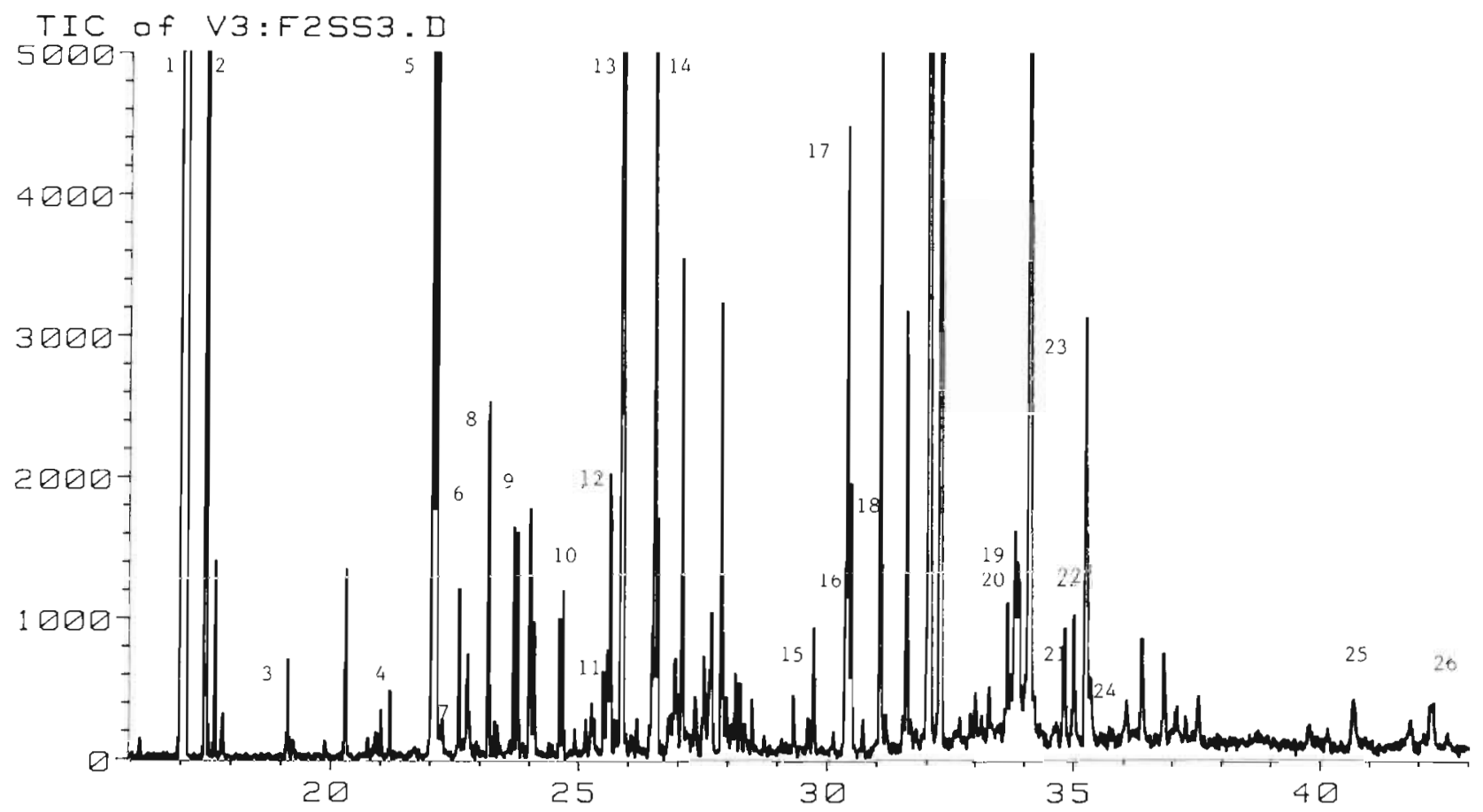

Fig. 4. Total ion chromatogram of semivolatile extractables in Fraction 2 from Silver Stream Reservoir. Identified peaks: 1. Hexamethylbenzene; 2, d-10 acenaphthene; 3, fluorene; 4, methylfluorenes; 5, d-10 phenanthrene; 6. phenanthrene; 7, anthracene; 8 , phthalate; 9 methylphenanthrenes; 10,2 -phenylnaphthalene; 11 , dimethylphenanthrenes; 12 , sulfur; 13 , fluoranthene; 14 , pyrene; 15 , benzo(ghi)fluoranthene; 16 , benz(a)anthracene; $17, d-12$ chrysene; 18 , chrysene; 19, benzo(b)fluoranthene; 20, benzo(k)fluoranthene; 21 , benzo(a)pyrene; 22, benzo(e)pyrene; $23, \mathrm{~d}-12$ perylene; 24 , perylene; 25, ideno(1,2,3-cd)pyrene; 26 , benzo(ghi)perylene

\section{Mutagenicity of sediments}

Statistical analysis showed that there were no significant differences in the $\mathrm{S} 9$ activating ability of individual fish within a species. Therefore, results from each individual yellow or brown bullhead could be pooled amongst species. Analysis also revealed no significant differences in the mutagenic response of sediments using S9 from brown bullhead fish collected in 1986 and 1987. The 4 fractions of Silver Stream Reservoir sediment extract were evaluated for mutagenicity in the Ames assay using Salmonella typhimurium TA100 and TA98 in the presence of $1.0 \mathrm{mg} \mathrm{S9}$ protein per plate from 3 sources: (1) a pooled sample from 3 yellow bullheads; (2) S9 from an individual brown bullhead; (3) pooled S9 from 4 rats pretreated with Aroclor 1254. The results of the assays using TA100 are summarized in Table 4. Toxicity, which may have been due to an unidentified white precipitate, was observed on the experimental plates when $100 \mu \mathrm{l}$ of Fraction 1 was added in the presence of all three S9 preparations. When 50 and $100 \mu \mathrm{l}$ of Fraction 2 were added to the experimental plates in the presence of $\$ 9$ from Aroclor pretreated rats, a significant increase $(p \leq 0.05)$ in the number of revertants/plate was observed compared to the background reversion rate. A significant increase in response was observed when $30 \mu \mathrm{l}$ of Fraction 3 was added to the plates containing rat S9. A similar study to evaluate the mutagenicity of Fractions 2 and 3 from sediments collected at Station 1 was undertaken in the presence of Salmonella typhimurium TA98 (Table 5). An increase in the mutagenic response was observed when 30 and $50 \mu \mathrm{l}$ of Fraction 2 were tested in the presence of S9 from Aroclor pretreated rats. Neither S9 fractions from yellow nor brown bullheads activated components of the sediment extracts to mutagens in the presence of either Salmonella strain.

\section{DISCUSSION}

Papillomas have been reported in many fish species (Wellings 1969, Mawdesley-Thomas 1971, 1975) including ictalurid fishes from a number of locations (Harshbarger 1977). A viral etiology for papillomas in a brown bullhead from a natural lake has been proposed (Edwards \& Samsonoff 1977). Also, more than $29.6 \%$ of white suckers Catostomus commersoni from the heav- 
level of papillomas in brown bullheads are worthy of further investigation. The lesions were host specific, being found predominantly on brown bullheads and not yellow bullheads that inhabit the same body of water. The yellow bullheads had a more active microsomal enzyme system that may conceivably detoxify a chemical more efficiently than that of the brown bullhead (Shane unpubl.). Conversely, the brown bullhead may metabolize a specific procarcinogen to a carcinogenic intermediate more efficiently than the yellow bullhead. To test this hypothesis, a study of the metabolites produced from benzo(a)pyrene or other PAH by the 2 fish species will be undertaken.

Although we have no definitive evidence regarding the etiological factors, we do have some reservations with the hypothesis that one or more carcinogens are associated with the development of the papillomas. Several case submissions of brown bullheads with papillomas have been made to the Fish Pathology Laboratory at the CVM at Comell University. Some of these fish originated from municipal reservoirs where the prevalence of the lesion is purported to be high. It would be expected that bodies of water used as drinking water sources would be less likely to contain carcinogens, compared to bodies of waters which are not as carefully monitored and controlled.

The possibility of a viral etiology deserves further consideration. The fact that virus particles were not observed by EM is by no means definitive evidence that a virus is not associated with the lesion. Seasonality or environmental temperature are factors that may have contributed to the papillomas observed in brown but not yellow bullheads taken from Silver Stream Reservoir. No bullheads with papillomas were caught in the summer (Jul 1987) while a large percentage of fish collected in the fall (Oct 1985 and 1986) had these lesions. Such a seasonal variation is not unknown in fish (Mulcahy \& O'Rourke 1964, Mulcahy \& O'Leary 1970, Peters \& Peters 1977, Bowser et al. 1988). In the latter case, a difference in temperature and season was correlated with the presence of retrovirus-like particles, the known etiologic agent of dermal sarcoma of walleye, which were seen in fish caught in the spring but not in those collected in the fall (Bowser et al. 1988). A virus associated with the papilloma of brown bullheads may behave in a similar manner and only be present as an intact particle during a limited period of the year. Future studies to investigate the relationship of seasonality with the possibility of a viral etiology are planned.

Acknowledgements. The authors gratefully acknowledge the technical assistance of the personnel of Region 3 of the New York State Department of Environmental Conservation for the collection of field samples. We also thank Anita L. Aluisio for preparation of microsomal and S9 fractions from the fish collected in 1986 and for gross trimming of tissues and histological processing and Teena Smith for performing assays to identify papilloma virus antigen. Debra McMillin aided in the analysis of the sediments. This work was funded in part through the New York State Return a Gift to Wildlife Fund.

\section{LITERATURE CITED}

Baumann, P., Harshbarger, J. C. (1985). Frequencies of liver neoplasia in a feral fish population and associated carcinogens. Mar. environ. Res. 17: 324-327

Baumann, P., Smith, W. D., Ribick, M. (1982). Hepatic tumor rates and polynuclear aromatic hydrocarbon levels in two populations of brown bullheads (Ictalurus nebulosus). In: Cooke, M., Dennis, A. J., Fischer, G. L. (eds.) Polynuclear aromatic hydrocarbons: physical and biological fate. Battelle Press, Columbus, Ohio, p. 93-102

Bemas, B. (1968). A new method for decomposition and comprehensive analysis of silicates by atomic absorption spectrophotometry. Analyt. Chem. 40: 1682-1686

Black, J. J., Evans, E. O., Harshbarger, J. C., Ziegel, R. F. (1982). Epizootic neoplasms in fishes from a lake polluted by copper mining wastes. J. Nat. Cancer Inst. 69: 915-926

Black, J. J. (1983a). Epidermal hyperplasia and neoplasia in brown bullheads (Ictalurus nebulosus) in response to repeated applications of PAH containing extract of polluted river sediment. In: Cooke, M., Dennis, A. J., Fisher, G. L. (eds.) Polynuclear aromatic hydrocarbons. Battelle Press, Columbus, Ohio, p. 99-111

Black, J. J. (1983b). Field and laboratory studies of environmental carcinogenesis in Niagara River fish. J. Great Lakes Res, 9: 326-334

Bowser, P. R., Wolfe, M. J., Forney, J. L., Wooster, G. A. (1988). Seasonal prevalence of skin tumors from walleye (Stizostedion vitreum) from Oneida Lake, New York. J. Wildl. Dis. 24: 292-298

Environmental Protection Agency (EPA) (1981). Procedure for sediment samples, method 1: direct flame atomic absorption, total metals. In: Procedures for handling and chemicals analysis of sediment and water samples. EPA Technical Report CE-81-1, p. 3.96-3.109

Environmental Protection Agency (EPA) (1983). Method 150.1 (electrometric). In: Methods for Chemical Analysis of Water and Wastes. U.S. EPA, Environmental Monitoring and Support Laboratory, Cincinnati, Ohio. EPA-600/4-79020

Edwards, M. R., Samsonoff, W. A. (1977). Electron microscopic observation of virus-like particles of a catfish papilloma. In: Bailey, G. W (ed.) Proceedings of the 35th Annual Meeting of the Electron Microscopy Society of America, Boston, p. 394-395

Fabacher, D. L., Schmitt, C. J., Besser, J. M. (1988). Chemical characterization and mutagenic properties of polycyclic aromatic compounds in sediment from tributaries of the Great Lakes. Envir. Toxic. Chem. 7: 529-543

Gardner, W H. (1965). Water content. In: Black, C. A. (ed.) Methods of soil analysis, Part 1, Physical and mineralogical properties including statistics of measurement and sampling. American Society of Agronomy Inc., Madison, WI, p. $92-127$

Grizzle, J. M., Melius, P., Strength, D. R. (1984). Papillomas on fish exposed to chlorinated wastewater effluent. J. Nat. Cancer Inst. 73: 1133-1142

Grizzle, J. M., Schwedier, T. E., Scott, A. L. (1981). Papillomas of black bullheads, Ictalurus melas (Rafinesque), living in a chlorinated sewage pond. J. Fish Dis. 4: 345-351 
Guengerich, F. P. (1977). Separation and purification of multiple forms of microsomal cytochrome P-450: activities of different forms of cytochrome P-450 towards several compounds of environmental interest. J. biol. Chem. 252: 3970-3979

Hard, G. C., Williams, R., Lee, J. (1979). Survey of demersal fish in Port Phillip Bay for incidence of neoplasia. Aust. J. mar. Freshwat Res. 30: 73-79

Harshbarger, J. C. (1977). Role of the registry of tumors in lower animals in the study of environmental carcinogenesis in aquatic animals. Ann. N.Y Acad. Sci. 298: $280-289$

Harshbarger, J. C. (1981). Activities report registry of tumors in lower animals, 1981 Supplement. Smithsonian Institute, Washington, D.C., p. 1-52

Hatch, W. R., Ott, W. L. (1968). Determination of sub-microgram quantities of mercury by atomic absorption spectrophotometry. Analyt. Chem. 40: 2085

Kleinow, K. M., Melancon, M. J., Lech, J. J. (1987). Biotransformation and induction: implications for toxicity, bioaccumulation and monitoring of environmental xenobiotics in fish. Envir. Hith Perspectives 71: 105-119

Kurelec, B., Protic, M., Britvic, S., Kezic, N., Rijavec, M., Zahn, R. K. (1981). Toxic effects in fish and the mutagenic capacity of water from the Sava River in Yugoslavia. Bull. envir. Contam. Toxic. 26: 179-187

Lake, B. G. (1987). Preparation and characterization of microsomal fractions for studies on xenobiotic metabolism In: Snell, K., Mullock, B. (eds.) Biochemical toxicology: a practical approach. IRL Press, Oxford, p. 183-215

Lowry, O. H., Rosebrough, N. J., Farr, A. L., Randall, R. J. (1951). Protein measurement with Folin phenol reagent. J biol. Chem. 15: 265-275

Malins, D. C., Hodgins, H. O. (1981). Petroleum and marine fishes: a review of uptake, disposition, and effects. Envir Sci. Technol. 15: 1272-1279

Malins, D. C., McCain, B. B., Meyers, M. S., Brown, D. W Krahn, M. M., Roubal, W. T., Schiewe, M. H., Landahl, J. T., Chan, S. L. (1987). Field and laboratory studies of the etiology of liver neoplasms in marine fish from Puget Sound. Envir. Hlth Perspectives 71: 5-16

Maron, D., Ames, B. N. (1983). Revised methods for the salmonella mutagenicity test. Mutation Res. 113: 173-215

Martineau, D., Bowser, P. R., Wooster, G. A., Armstrong, L. D. (1990). Experimental transmission of dermal sarcoma in fingerling walleyes (Stizostedion vitreum). Vet. Pathol. 27 230-234

Mawdesley-Thomas, L. E. (1971). Neoplasia in fish: a review. Adv. Pathobiol, 1. 88-170

Mawdesley-Thomas, L. E. (1975). Neoplasia in fish. In: Ribelin, W. E., Migaki, G. (eds.) The pathology of fishes. The University of Wisconsin Press, Madison, WI, p. 805-870

Mix, M. C. (1986). Cancerous diseases in aquatic animals and their association with environmental pollutants: a critical literature review. Mar. environ. Res. 20: 1-141
Möller, H. (1984). Dynamics of fish diseases in the lower Elbe River. Helgoländer Meeresunters. 37: 389-413

Mulcahy, M. R., O'Leary, A. (1970). Cell-free transmission of lymphosarcoma in the northern pike Esox lucius L. (Pisces, Esocidae). Experientia 26: 891

Mulcahy, M. R., O'Rourke, R. J. (1964). Lymphosarcoma in the pike (Esox lucius L.) in Ireland. Life Sci. 3: 719-720

Neff, J. M., Cox, B. A., Dixit, D., Anderson, J. W. (1976). Accumulation and release of petroleum-derived aromatic hydrocarbons by four species of marine animals. Mar. Biol. 38: 279-289

Payne, J. F., Kiceniuk, J., Fancey, L. L., Williams, U. (1988) What is a safe level of polycyclic aromatic hydrocarbons for fish. subchronic study on winter flounder (Pseudopleuronectes americanus). Can. J. Fish. Aquat. Sci. 45: 1983-1993

Pauwels, S. J., Haines, T. A. (1986). Fish species distribution in relation to water chemistry in selected Maine lakes. Wat. Air Soil Pollut. 30: 477-488

Pesch, G. G., Malcolm, A. R., Gardner, G. R. (1987). Application of biomarkers to predict organism response following exposure to contaminated marime sediments. 8th Annual meeting of the Society of Environmental Toxicology and Chemistry, Pensacola, FL, p. 128 (Abstract)

Peters, G., Peters, N. (1977). Temperature-dependent growth and regression of epidermal tumors in the European eel (Anguilla anguilla). Ann. N.Y Acad. Sci. 298: 245-260

Reimer, J. A. (1989). An investigation of the possible etiology of papillomas in bullheads from a reservoir in New York State. M.S. thesis, Louisiana State University, Baton Rouge, LA

Russel, F. E., Kotin, P. (1957). Squamous papillomas in the white croaker. J. Nat. Cancer Inst. 18: 857-861

Shikota, T. (1976). Primary liver carcinoma and liver cirrhosis In: Okuda, K., Peters, R. L. (eds.) Hepatocellular carcinoma. Wiley, New York, p. 53-71

Smith, C. E., Peck, T. H., Klauda, R. J., McLaren, J, B. (1979) Hepatumas in atlantic tomcod Microgodus tomcod (Walbaum) collected in the Hudson River estuary in New York. J. Fish Dis. 2: 313-319

Smith, D. L., Underwood, J. K., Ogden, J. G., Sabean, B. C. (1986). Fish species distribution and water chemistry in Nova Scotia lakes. Wat. Air Soil Pollut. 30:489-496

Sonstegard, R. A. (1976). Studies of the etiology and epizootiology of lymphosarcoma in Esox (Esox lucius) and (Esox masquinongy). Prog. exp. Tumor Res. 20: 141-155

Sonstegard, R. A. (1977). Environmental carcinogenesis studies in fishes of the Great Lakes of North America. Ann. N.Y. Acad. Sci. 298: 261-269

Weakley, B. S. (1972). A beginner's handbook in biological electron microscopy. Churchill Livingston, Edinburgh

Wellings, S. R. (1969). Neoplasia and primitive vertebrate phylogeny: echinoderms, prevertebrates and fishes - a review. Nat. Cancer Inst. Monogr. 31: 59-128

Young, P. H. (1964). Some effects of sewer effluent on marine life. Calif. Fish Game 50: 33-41

Manuscript first received: December 17, 1990

Revised version accepted: June 1, 1991 